\title{
ORAL FOCAL MUCINOSIS: CASE REPORT
}

\author{
F. GERMANO*, R. ABATE**, F. SANTINI***, M. DRI****, C. ARCURI***** \\ * Contract Professor of Periodontology, University of Rome "Tor Vergata”, Rome, Italy \\ "S. Giovanni Calibita” Fatebenefratelli Hospital, Isola Tiberina, Rome, Italy \\ **Doctor in Dentistry, "S. Giovanni Calibita" Fatebenefratelli Hospital, Isola Tiberina, Rome, Italy \\ *** Doctor in Dentistry, AFaR “S. Giovanni Calibita” Fatebenefratelli Hospital, Isola Tiberina, Rome, Italy \\ **** Doctor in Dentistry and Consultant in periodontology and Implantology, "S. Giovanni Calibita” Fatebenefratelli Hospital, \\ Isola Tiberina, Rome, Italy \\ ***** Professor and Chairman, Department of Odontostomatology, AFaR "S. Giovanni Calibita” Fatebenefratelli Hospital, \\ Isola Tiberina, Rome, Italy - Professor of Periodontology, University of Rome "Tor Vergata”, Rome, Italy
}

\section{SUMMARY}

Oral focal mucinosis: case report

Oral focal mucinosis (OFM) is an uncommon disease of unknown aetiology. It is considered to be the oral counterpart of cutaneous focal mucinosis and cutaneous myxoid cyst and it is characterized by a focal myxoid degeneration of the connective tissue. A preoperative diagnosis is almost impossible, and the clinical suspicion, usually made by exclusion, must be confirmed by a bioptic examination followed by histological observations.

The Authors report a case of focal oral mucinosis diagnosed and treated in a male adult patient.

Key words: oral focal mucinosis, gingiva, biopsy.

\section{RIASSUNTO}

Mucinosi orale focale: caso clinico

La mucinosi orale focale è una patologia rara dall'eziologia sconosciuta. È considerata la manifestazione orale della mucinosi focale cutanea e della cisti mixoide cutanea. Caratterizzata da una degenerazione focale del tessuto connettivo. Una diagnosi preoperatoria non è possibile e il sospetto clinico, in genere fatto per esclusione, deve essere confermato da esame bioptico seguito da osservazione istologica. Gli autori descrivono un caso di mucinosi orale focale trattata in un paziente adulto.

Parole chiave: mucinosi orale focale, gengiva, biopsia.

\section{Introduction}

Oral focal mucinosis (OFM) is a rare disease that affects different localised areas of the mouth, where the connective tissue undergoes a focal degeneration. It has been described for the first time by Tomich in 1973 (1) and only few cases have been described in literature $(2,6)$, two of them observed on tongue (7). It is considered to be the oral expression of the focal skin mucinosis and myxoid skin cysts, thus presenting specific histological features (8). Focal skin mucinosis can be seen as a lesion of mesenchymal origin in which fibroblasts predominate. In oral focal mucinosis there is a hyaluronic acid overproduction by fibroblasts that reduce the production of col- lagen, elastic fibers, almost absent, and collagen fibers that disgregate and are replaced by varying amounts of mucin. Skin onsets seem not to be associated with oral lesions.

The diagnosis of OFM is usually made by exclusion: an area of similar myxoid tissue is found in the inflammatory fibroepithelial hyperplasia, lesion objectively characterized by inflammation and fibrosis (9). Differential diagnosis can be made with mixoma, that is expressed as an oral soft tissues lesion with compromise of the underlying bone, showing well circumscribed and distinguishable from surrounding tissue. OFM appears with rather blurred margins confusing with tissues that surround it, without damaging adjacent anatomical structures. Most of inflammatory lesions, such as gingivitis, fibrous hyperplasia, 
epulis, pyogenic granuloma or tumors, such as peripheral fibroma and ossifying fibroma, and nonplaque associated lesions manifesting as a swelling gum, as mucocele, create differential diagnosis problems with focal oral mucinosis (10). In any case, to confirm the clinical suspicion a bioptic examination followed by histological observations is needed.

OFM frequently affects women in a wide range of age, localizing in $80 \%$ of cases at the gum, generally in the jaw, and secondly in the palatal region, on the lips or tongue.

It clinically presents as a swelling that does not exceed $2 \mathrm{~cm}$ in diameter, sessile of firm consistency, that mimics in the surrounding mucosa for colour, and is generally asymptomatic.

The aetiology remains still now unknown. Surgical treatment is the unique therapy. OFM generally does not tend to give relapse.

\section{Case report}

A 35 years old male patient, non-smoker, with good oral hygiene and a swelling localized in the vestibular attached gingiva of the upper right central incisive (Figs. 1,2) came to our observation. His medical and dental history was noncontributory. The rounded of about $10 \mathrm{~mm}$ in diameter lesion was sessile, with hard consistency, adherent to the underlying tissues and pinkish in colour. Surgery excisional biopsy was scheduled. Prior local anesthesia with $2 \%$ mepivacaine and vasoconstrictor 1:1.000.000, a partial thickness circular excision of the swelling, that presented bluish-grey in colour, was performed (Fig. 3). Macroscopic examination of the lesion did not give any indications for a diagnosis. Healing was asymptomatic and without recurrence at 6 months from surgery. Histological examination diagnosed a oral focal mucinosis (11).

At histological examination the lesion appeared to be as a myxoid tissue (Pas Alcian+) in which fusiform or stellate fibroblasts were immersed. The absence of flogosis and fibrosis excluded the inflammatory fibroepithelial hyperplasia (Figs. 4, 5) and permitted the diagnosis of oral focal mucinosis.

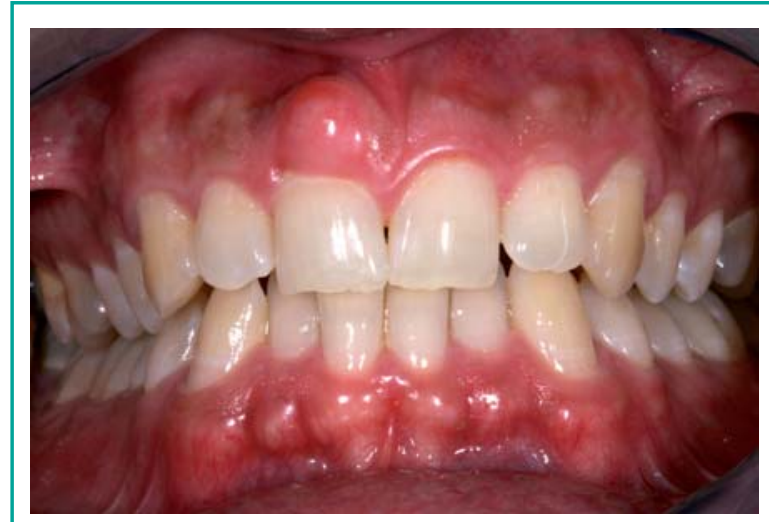

Figure 1

Intra-oral aspect of patient's mouth. An elevated mass can be observed located on the gingiva of the right upper central incisor.

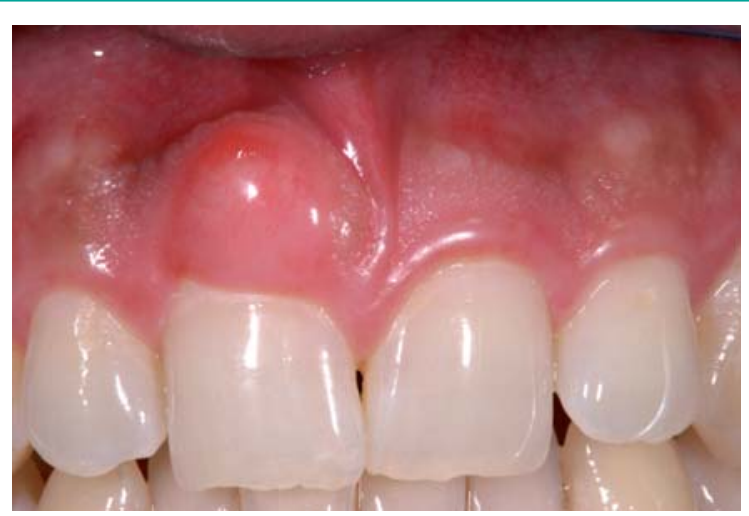

\section{Figure 2}

Intra-oral particular of the gingival rounded lesion. At the clinical examination it appears to be sessile, with hard consistency, adherent to the underlying tissues and pinkish in colour. The lesion measured about $10 \mathrm{~mm}$ in diameter.

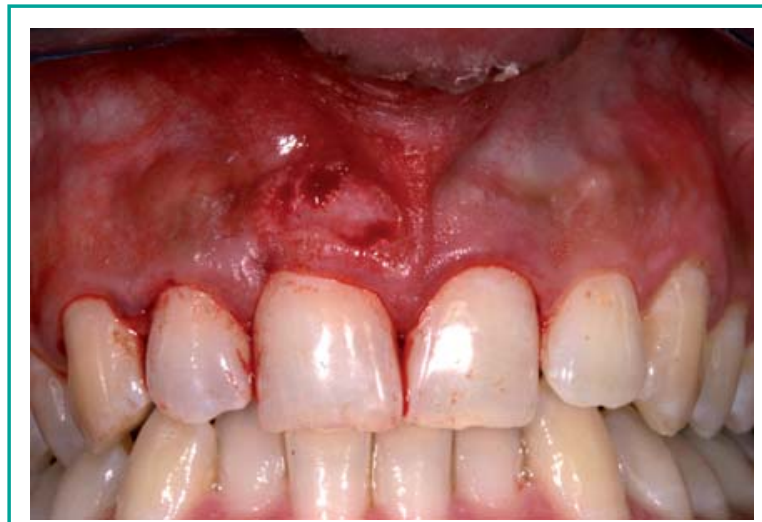

Figure 3

The site immediately after surgical excisional biopsy of the lesion. 


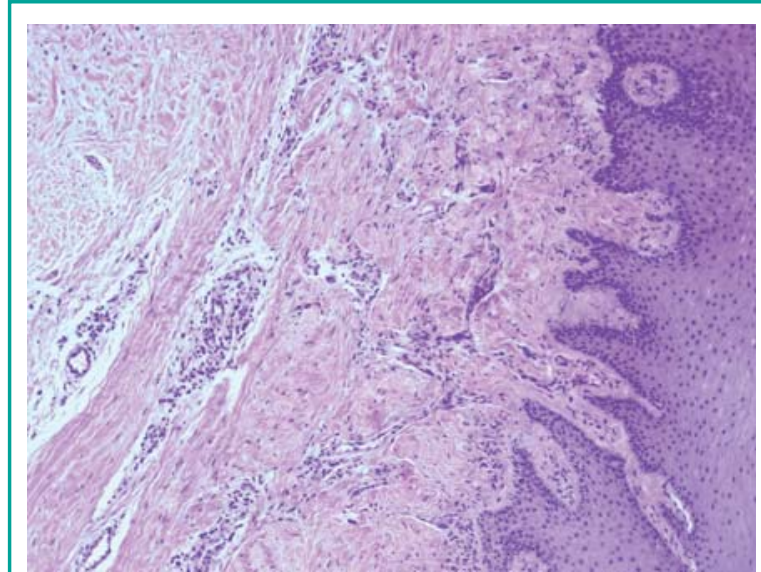

\section{Figure 4}

Histological examination of the lesion: paraffin section. The lesion appeared to be as a myxoid tissue (Pas Alcian +) in which fusiform or stellate fibroblasts were immersed 200X.

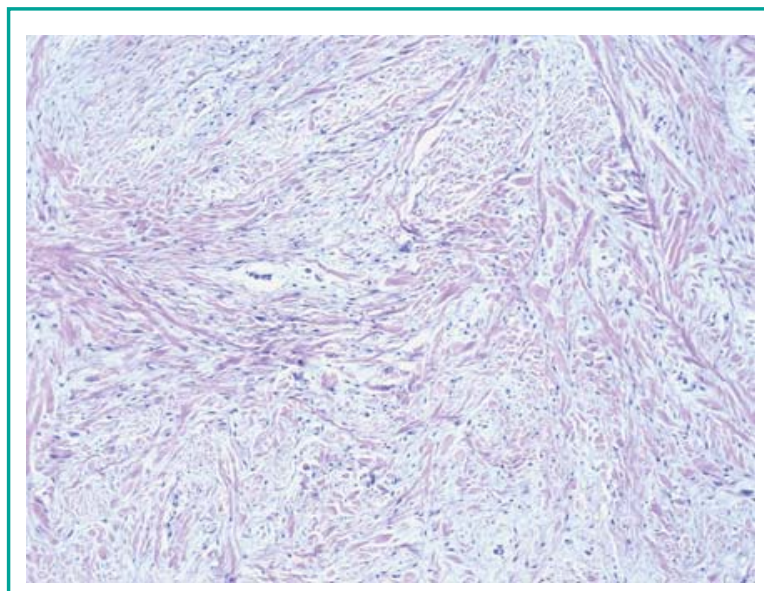

\section{Figure 5}

Histological examination of the lesion: 500X.

\section{References}

1. Tomich CE. Oral Focal Mucinosis. Oral Surg Oral Med Oral Pathol 1974; 38: 714-724.

2. Aldred MJ, Talacko AA, Ruljancich K, Story RD, Newland S, Chen ST, O'Grady JF, Bergman JD, Smith A, Dimitroulis G, Redman J, Sheldon WR, Mansour AK, Watkins D, Radden BG. Oral focal mucinosis: report of 15 cases and review of the literature. Pathology 2003 Oct; 35 (5): 393-6.

3. Buchner A, Merrell PW, Leider AS, Hansen LS. Oral focal mucinosis. Int J Oral Maxillofac Surg. 1990 Dec; 19 (6): 337-40.

4. Iezzi G, Rubini C, Fioroni M, Piattelli A. Oral focal mucinosis of the gingiva: case report. J Periodontol 2001 Aug; 72 (8): 1100-2.

5. Saito I, Ide F, Enomoto T, Kudo I. Oral focal mucinosis. J Oral Maxillofac Surg. 1985 May; 43 (5): 372-4.

6. Talacko AA, Lacy MF, Besly WJ, Aldred MJ. Oral focal mucinosis: report of two cases with ulceration. Pathology 2004 Dec; 36 (6): 582-3.

7. Soda G, Baiocchini A, Bosco D, Nardoni S, Melis M. Oral Focal Mucinosis of The Tongue. Pathol Oncol Res 1998; 4: 304-307.

8. Wilk M, Schmoekel C. Cutaneous focal mucinosis. A histopathological and immunohistochemical analysis of 11 cases. J Cutan Pathol 1994; 21: 446452.

9. Elzay RP, Dutz W. Myxomas of the paraoral/oral soft tissues. Oral Surg Oral Med Oral Pathol 1978; 45: 246-254.

10. Manor Y, Merdinger O, Katz J, Ticher S. Unusual peripheral odontogenic tumors in the differential diagnosis of gingival swellings. J Clin Periodontol 1999; 26: 806-809.

11. Odell EW, Morgan PR. Biopsy Pathology of the oral tissues. London: Chapman \& Hall 1998; 144-146.

\section{Correspondence to:}

Dott. Francesco Germano

Via di Ponte Quattro Capi, 39

Isola Tiberina

00100 Rome

E-mail: francesco.germano@ fastwebnet.it 